\title{
Mobilitas Manusia dan Tingkat Penyebaran Covid-19: Sebuah Analisis Kuantitatif
}

\section{(Human Mobility and Covid-19 Transmission: A Quantitative Analysis)}

\author{
Lukito Edi Nugroho ${ }^{1}$, Arkham Zahri Rakhman ${ }^{1,2}$
}

\begin{abstract}
The Covid-19 pandemic has created many uncertainties and decisions are often made without the support of undisputable facts. The presentation of facts based on quantitative data becomes an important factor to improve the quality of decisions. This paper aims at building support for pandemic fact provisioning through a quantitative approach. Using community mobility data and data on Covid-19 daily transmission rate, this study analyzes the correlation between these two factors in the Special Region of Yogyakarta. Correlation was calculated between daily Covid-19 transmission rate and community mobility in six types of areas that could be linked to social gathering. In the time span between March 2020 and March 2021, the correlation between the daily transmission rate and community mobility in all areas was low (correlation coefficient between 0.03 and 0.33 ). The result explained that reduced community mobility developed social distancing, which was effective in controlling virus transmission. However, in shorter time spans which contain spikes in mobility to public destination areas triggered by several long holidays, the correlation between the increase of daily Covid-19 cases and the 'stay at home' activity increased significantly (correlation coefficient 0,64 ). This showed the fact that Covid-19 spread is characterized more by family clusters.
\end{abstract}

Intisari-Pandemi Covid-19 menimbulkan banyak ketidakpastian dan sering kali pengambilan keputusan harus diambil tanpa dukungan fakta yang meyakinkan. Penyajian fakta berbasis data kuantitatif menjadi faktor penting untuk meningkatkan kualitas keputusan. Makalah ini bertujuan membangun dukungan bagi penyajian fakta terkait situasi pandemi melalui pendekatan kuantitatif. Dengan menggunakan data mobilitas masyarakat dan data pertambahan kasus harian Covid-19, makalah ini menganalisis korelasi antara kedua faktor tersebut di Provinsi Daerah Istimewa Yogyakarta. Korelasi dihitung antara pertambahan kasus harian Covid-19 dengan mobilitas pada enam jenis area yang dapat dikaitkan dengan aktivitas social gathering. Pada rentang waktu selama Maret 2020 sampai dengan Maret 2021, korelasi antara pertambahan harian kasus Covid-19 dan mobilitas masyarakat pada semua area cenderung rendah (koefisien korelasi berkisar dari 0,03 sampai dengan 0,33). Hal ini mengindikasikan terbentuknya mekanisme social distancing akibat penurunan tingkat mobilitas masyarakat, yang membuat tingkat penyebaran Covid-19 relatif terkontrol. Pada rentang waktu yang lebih pendek dan mengandung

${ }^{1}$ Departemen Teknik Elektro dan Teknologi Informasi, Jalan Grafika 2, Yogyakarta 55281, Indonesia (tlp dan fax: 0274552305/547506; e-mail: lukito@ugm.ac.id)

${ }^{2}$ Jurusan Teknologi Produksi dan Industri, Institut Teknologi Sumatera, JL. Terusan Ryacudu, Way Huwi, Jati Agung, Lampung Selatan, Indonesia (telp: (0721)8030188, fax: (0721)8030189; $e$ mail:arkham@if.itera.ac.id) lonjakan-lonjakan mobilitas ke area-area tujuan publik yang dipicu oleh beberapa libur panjang, korelasi antara pertambahan kasus harian Covid-19 dengan aktivitas 'tinggal di rumah' meningkat secara drastis (koefisien korelasi 0,64). Hal ini menjelaskan fenomena penyebaran virus Covid-19 lebih dicirikan dengan penularan melalui klaster keluarga.

Kata Kunci- Mobilitas Manusia, Tingkat Penyebaran Covid-19, Analisis Korelasi, Pengambilan Keputusan.

\section{Pendahuluan}

Di banyak negara, penyebaran virus Covid-19 berlangsung dengan sangat cepat. Berdasarkan data yang dihimpun Gugus Tugas Percepatan Penanganan Covid-19, sejak ditemukannya kasus Covid-19 pertama kali di Indonesia pada awal bulan Maret 2020, per tanggal 28 Februari 2021 tercatat 1.334 .634 kasus terkonfirmasi dan separuh dari jumlah tersebut baru muncul menjelang akhir tahun 2020 [1]. Hal ini menunjukkan akselerasi penularan yang cepat.

Data yang sama juga menunjukkan bahwa lonjakan kasus terjadi beberapa hari setelah libur panjang. Data Jasa Marga menunjukkan bahwa dalam sembilan hari pada periode libur Natal dan tahun baru terjadi lonjakan pergerakan masyarakat yang cukup masif: 1,2 juta kendaraan meninggalkan Jakarta [2]. Dengan membandingkan antara fakta meningkatnya penyebaran Covid-19 dengan fakta meningkatnya mobilitas masyarakat, dapat dilihat adanya korelasi positif antara keduanya. Analisis kualitatif terhadap fenomena ini adalah bahwa mobilitas cenderung memicu terjadinya interaksi antar manusia dalam jarak yang cukup dekat dan hal ini memperbesar peluang terjadinya penularan karena virus SARS-CoV-2 menular antara lain melalui droplet yang dengan mudah bertransmisi dalam bentuk cairan atau aerosol [3], [4].

Fakta kualitatif pada umumnya mencukupi untuk menghadapi situasi secara umum, misalnya untuk keperluan sosialisasi dan edukasi untuk masyarakat [5]. Namun, situasi yang lebih kompleks atau spesifik memerlukan dukungan fakta yang spesifik dan tegas, lebih dari sekedar pernyataan kualitatif. Sebagai contoh, ketika Covid-19 mulai menyebar dengan masif, beberapa daerah menempuh bentuk-bentuk kebijakan yang berbeda terkait mobilitas masyarakat [6]. Perbedaan kebijakan ini muncul karena perbedaan data yang menunjukkan karakteristik lokal pada tiap daerah. Kondisi lokal sebagai basis pengambilan keputusan pada akhirnya menjadi dasar kebijakan pemerintah yang terkini dalam upaya penanggulangan penyebaran Covid-19, yaitu Pemberlakuan Pembatasan Kegiatan Masyarakat (PPKM) Mikro yang dijalankan mulai tanggal 5 Februari 2021 [7]. PPKM Mikro 
mengimplikasikan pandangan tentang pentingnya pemahaman terhadap kondisi lokal sebagai landasan penetapan kebijakan penanggulangan Covid-19 di sebuah area.

Dalam beberapa situasi spesifik, pengambilan keputusan berbasis area lokal memerlukan dukungan data primer yang diolah menjadi informasi yang relevan. Polemik penutupan objek wisata saat libur panjang, seperti kawasan Malioboro, Yogyakarta, saat malam pergantian tahun [8], menunjukkan bahwa tidak adanya kesamaan pengetahuan tentang fakta-fakta spesifik dan objektif dapat memunculkan persepsi yang berbeda. Pendekatan kuantitatif menjadi penting bagi pengambil keputusan untuk melakukan manajemen risiko dalam kondisi pandemi seperti ini. Membuka atau menutup objek wisata, menyelenggarakan atau membatalkan acara atau event tertentu, merencanakan penambahan fasilitas dan tenaga kesehatan, menyiapkan prioritas vaksinasi, dan berbagai langkah mitigasi risiko lainnya memerlukan dukungan data kuantitatif yang relevan.

Makalah ini bertujuan membangun dukungan bagi penyajian fakta terkait situasi pandemi melalui pendekatan kuantitatif. Secara lebih spesifik, makalah ini bertujuan menemukan korelasi antara mobilitas masyarakat dengan tingkat penularan virus SARS-CoV-2 pada daerah tertentu. Meskipun tampaknya sederhana, pemahaman terhadap korelasi ini memiliki peran yang sangat penting karena pengambil kebijakan lokal dapat menggunakan mobilitas masyarakat, sebuah aktivitas fundamental yang dilakukan masyarakat, sebagai instrumen vital dalam pengendalian penyebaran Covid-19. Pengambilan keputusan dapat dilakukan secara lebih objektif dan spesifik terhadap sebuah daerah, yang bisa saja berbeda dibandingkan dengan daerah yang lain. Dengan demikian, kontribusi langsung dari makalah ini adalah memberikan justifikasi terhadap kebijakan pengendalian penyebaran Covid-19 seperti PPKM Mikro. Dengan mengamati hubungan korelasi antara mobilitas masyarakat dengan tren penambahan kasus Covid19, pengambil kebijakan dapat menentukan mobilitas masyarakat perlu dibatasi atau tidak, seberapa jauh pembatasannya, seberapa luas area yang dibatasi, dan seberapa lama pembatasan tersebut perlu dilakukan.

Secara metodologis, penelitian ini juga berkontribusi memberikan penjelasan tentang spesifikasi data yang diperlukan serta pengolahannya. Dengan memahami kebutuhan data dan cara pengolahannya, diharapkan analisis kuantitatif tentang keterkaitan antara mobilitas masyarakat dengan penyebaran Covid-19 dapat dilakukan oleh lebih banyak pihak. Dampaknya adalah semakin banyak daerah lain yang dapat menganalisis kondisinya sendiri dengan lebih mudah. Peningkatan kualitas pengambilan keputusan dapat direplikasi ke daerah-daerah lain secara lebih cepat.

Studi kasus yang dipilih adalah Provinsi Daerah Istimewa Yogyakarta (DIY). Provinsi DIY dipilih karena dua alasan: 1) sebagai daerah tujuan wisata yang populer, Provinsi DIY dapat merepresentasikan dinamika tingkat penularan Covid-19 yang dikaitkan dengan mobilitas masyarakat; dan 2) ketersediaan data yang memadai.

\section{Data Mobilitas Manusia Dalam Mitigasi PandEMI COVID-19}

Pandemi Covid-19 yang terjadi saat ini mengakibatkan risiko yang amat besar pada semua level, dari negara sampai ke kelompok masyarakat pada skala terbatas. Risiko besar ini muncul karena adanya derajat ketidakpastian yang tinggi dalam berbagai aspek yang menyulitkan pengambil keputusan untuk melakukan prediksi [9]. Sering kali "nasib" bangsa dipertaruhkan pada keputusan-keputusan strategis yang diambil berdasarkan situasi seperti ini [10].

Pada situasi krisis yang bersifat meluas, pengambilan keputusan terkait dengan mitigasi risiko dapat terjadi pada berbagai tingkatan, dari tingkat pemerintah pusat sampai ke tingkat satuan pemerintahan terbawah. Dalam semua tingkatan tersebut, pengambilan keputusan memerlukan dukungan data yang menunjukkan fakta tentang situasi yang dihadapi. Salah satu aspek yang sering mendapatkan perhatian dalam penanganan krisis penyakit menular adalah mobilitas manusia. Penularan penyakit pada umumnya disebabkan oleh dua hal: 1) mobilitas membawa patogen pembawa penyakit ke kelompok manusia yang rentan terhadap penyakit tersebut, atau 2) meningkatkan kontak antara manusia yang membawa penyakit dengan manusia-manusia lain yang rentan [11]. Beberapa studi mengonfirmasi adanya hubungan antara mobilitas manusia dengan penyebaran influenza [12], malaria [13], DHF [14], dan cacar (measles) [15].

Karena mobilitas manusia terbukti berpengaruh terhadap tingkat penyebaran, aspek mobilitas ini sering diangkat sebagai faktor penting dalam upaya pengendalian penyebaran penyakit menular. Sebuah model mobilitas jaringan global yang dikombinasikan dengan model epidemiologi lokal telah dikembangkan untuk meramalkan dinamika dan pengendalian wabah Covid-19 di Eropa [16]. Di China, pola-pola penularan virus SARS-CoV-2 yang terjadi di kota-kota di China dikaji dan dipahami menggunakan data mobilitas penduduk di Wuhan [17]. Terkait dengan penyebaran Covid-19 di Indonesia, penelitian yang mempelajari hubungan antara mobilitas masyarakat dari dalam dan ke luar kota Jakarta terhadap penyebaran Covid-19 di Jakarta menunjukkan adanya tingkat korelasi yang tinggi sehingga dalam rekomendasinya disampaikan pentingnya penerapan kebijakan pembatasan mobilitas penduduk secara efektif [18]. Penelitian-penelitian yang mempelajari hubungan antara mobilitas penduduk dan tingkat penyebaran Covid-19 menunjukkan pentingnya pemahaman tentang hal ini dalam proses-proses pengambilan keputusan, terutama dalam upaya penanggulangan dampak dan pencegahan penyebaran penyakit tersebut.

Ada beberapa cara untuk mendapatkan data mobilitas masyarakat, tetapi ciri khas sumber-sumber data ini adalah sifatnya yang personal dan mudah diagregasi untuk membentuk data crowd. Data mobilitas bisa diperoleh dari data lokasi telepon seluler yang bersifat anonim [18], [19]. Data mobilitas juga dapat diperoleh dari matriks Origin-Destination (OD) yang dibangun dari data panggilan telepon seluler (call detail records - CDR). Metode ini digunakan untuk mendeteksi perubahan pola mobilitas penduduk dan pengaruhnya terhadap 
kegiatan ekonomi lokal [20]. Cuitan (tweets) di Twitter juga dapat menjadi sumber data mobilitas. Geotag yang melekat pada setiap data cuitan dimanfaatkan untuk menentukan perpindahan lokasi pengguna, baik yang terjadi dalam hari yang sama, maupun pada hari yang berbeda [21]. Sumber data mobilitas yang bersifat agregat pun dapat digunakan untuk karakterisasi kondisi pandemi yang terjadi, seperti yang dilakukan di Mexico yang menggunakan data Covid-19 Community Mobility Reports dari Google [22] dan di China yang menggunakan data mobility index Baidu [23].

Penelitian ini mirip dengan penelitian yang mencermati hubungan korelasi antara mobilitas penduduk dengan jumlah konfirmasi kasus positif Covid-19 di Jakarta [18]. Perbedaan terletak pada sumber data yang digunakan. Penelitian di Jakarta menggunakan sumber data hasil pelacakan telepon seluler [18], sementara makalah ini menggunakan sumber data teragregasi dari Google (Covid-19 Community Mobility Reports) untuk Provinsi DIY. Selain itu, penelitian di Jakarta dilakukan dalam jangka waktu Maret-April 2020 [18], sementara penelitian ini mengamati dinamika mobilitas masyarakat pada periode waktu yang jauh lebih panjang, yaitu dari Maret 2020 sampai Maret 2021. Perbedaan area dan periode waktu pengamatan akan memberikan kajian mendalam (insights) yang berbeda, dengan kemanfaatan yang berbeda pula.

\section{METODOLOGI}

\section{A. Data}

Ada dua himpunan data (dataset) yang digunakan, yaitu data mobilitas masyarakat dan data penyebaran Covid-19. Data mobilitas masyarakat diperoleh dari Covid-19 Community Mobility Reports yang disusun oleh Google dan dapat diakses dari situs https://www.google.com/covid19/mobility/. Data ini merekam pergerakan manusia, yang diperoleh dari jejak pergerakan telepon seluler berbasis Android. Dengan algoritme tertentu, Google dapat mengidentifikasi mobilitas pengguna di area-area tertentu: pertokoan dan tempat rekreasi, tempat perbelanjaan dan apotek, taman, tempat transit transportasi, lingkungan perumahan, dan kompleks perkantoran. Tempattempat ini dipilih mewakili tempat-tempat yang biasanya menjadi lokasi terjadinya interaksi sosial.

Data dalam Covid-19 Community Mobility Reports dikelompokkan secara harian. Data tiap harinya menunjukkan tren naik atau tren turun mobilitas di area-area yang disebutkan di atas, yang dibandingkan dengan baseline tertentu. Google merekam data mobilitas ini sejak tanggal 2 Februari 2020 dan masih berlangsung sampai saat makalah ini ditulis. Dalam rentang waktu ini, data Covid-19 Community Mobility Reports menyajikan dinamika tren mobilitas masyarakat harian pada area-area tersebut.

Himpunan data tentang penyebaran Covid-19 diperoleh dari Pemerintah Provinsi DIY. Data ini merekam pertambahan kasus harian yang dikelompokkan berdasarkan tanggal, kejadian penambahan kasus baru, penambahan kesembuhan, dan penambahan kematian. Data dalam penelitian ini berasal dari periode 21 Maret 2020 sampai dengan 3 Maret 2021.

\section{B. Analisis}

Analisis dilakukan dengan memasangkan data mobilitas masyarakat dengan data pertambahan kasus harian Covid-19 pada sumbu waktu yang sama. Dengan basis waktu (harian), korelasi antara mobilitas masyarakat dan pertambahan kasus Covid-19 dihitung dengan metode Pearson. Tren pertambahan kasus dilihat terhadap enam jenis area: pertokoan dan tempat rekreasi, tempat perbelanjaan dan apotek, taman dan fasilitas publik, tempat transit transportasi, perumahan, dan kompleks perkantoran. Keenam jenis area ini akan menjadi variabel bebas yang menentukan variabel terikat berupa pertambahan kasus harian. Korelasi Pearson multivariabel ini dapat dihitung menggunakan (1).

$$
R_{x 1, x 2, \ldots, x 6 . y}=\sqrt{\frac{b 1 \cdot \sum x 1 y+b 2 \cdot \sum x 2 y+\cdots+b 6 \cdot \sum x 6 y}{\sum y^{2}}}
$$

dengan

$$
\begin{gathered}
\sum y^{2}=\sum Y^{2}-\frac{\left(\sum Y\right)^{2}}{n} \\
\sum x_{i} y=\sum X_{i} Y-\frac{\left(\sum X_{i}\right)\left(\sum Y\right)}{n}
\end{gathered}
$$

dan

$$
\begin{aligned}
n & =\text { jumlah data (347 data) } \\
\sum X_{i} & =\text { jumlah data } X_{i} \\
\sum Y & =\text { jumlah dari } Y \\
\sum Y^{2} & =\text { jumlah dari } Y^{2} \\
\sum X_{i} Y & =\text { jumlah dari } X_{i} Y .
\end{aligned}
$$

Perhitungan dalam (1) dilakukan menggunakan aplikasi Microsoft Excel.

Visualisasi data dilakukan menggunakan aplikasi Datawrapper (https://datawrapper.de). Dengan masukan berupa data mobilitas dan data pertambahan kasus harian, aplikasi ini menampilkan visualisasi data dalam bentuk grafik yang dapat diberi penjelasan (anotasi) seperlunya. Grafik yang dihasilkan memungkinkan data dianalisis secara visual untuk memberikan pemaknaan secara cepat.

\section{HASIL DAN PEMBAHASAN}

\section{A. Visualisasi Data dan Analisisnya}

Gbr. 1 menunjukkan tren pertambahan kasus harian Covid19 yang disandingkan dengan tren mobilitas masyarakat pada keenam jenis lokasi. Data diambil dari periode 21 Maret 2020 sampai 3 Maret 2021 dan divisualisasikan menggunakan aplikasi Datawrapper.

Dari Gbr. 1 terlihat pola perilaku mobilitas masyarakat selama periode pandemik ini. Di saat awal, ketika mulai diberlakukan kebijakan pembatasan mobilitas untuk pertama kali, terjadi penurunan mobilitas masyarakat yang sangat signifikan (ditunjukkan dengan nilai negatif yang cukup tinggi). Namun, seiring berjalannya waktu, tingkat pergerakan ini meningkat meskipun belum mencapai kondisi normal sebelum pandemi. Ketika kebijakan PPKM tahap I diberlakukan, tingkat mobilitas kembali menurun, tetapi dengan cepat merangkak naik kembali, meskipun ada kebijakan 


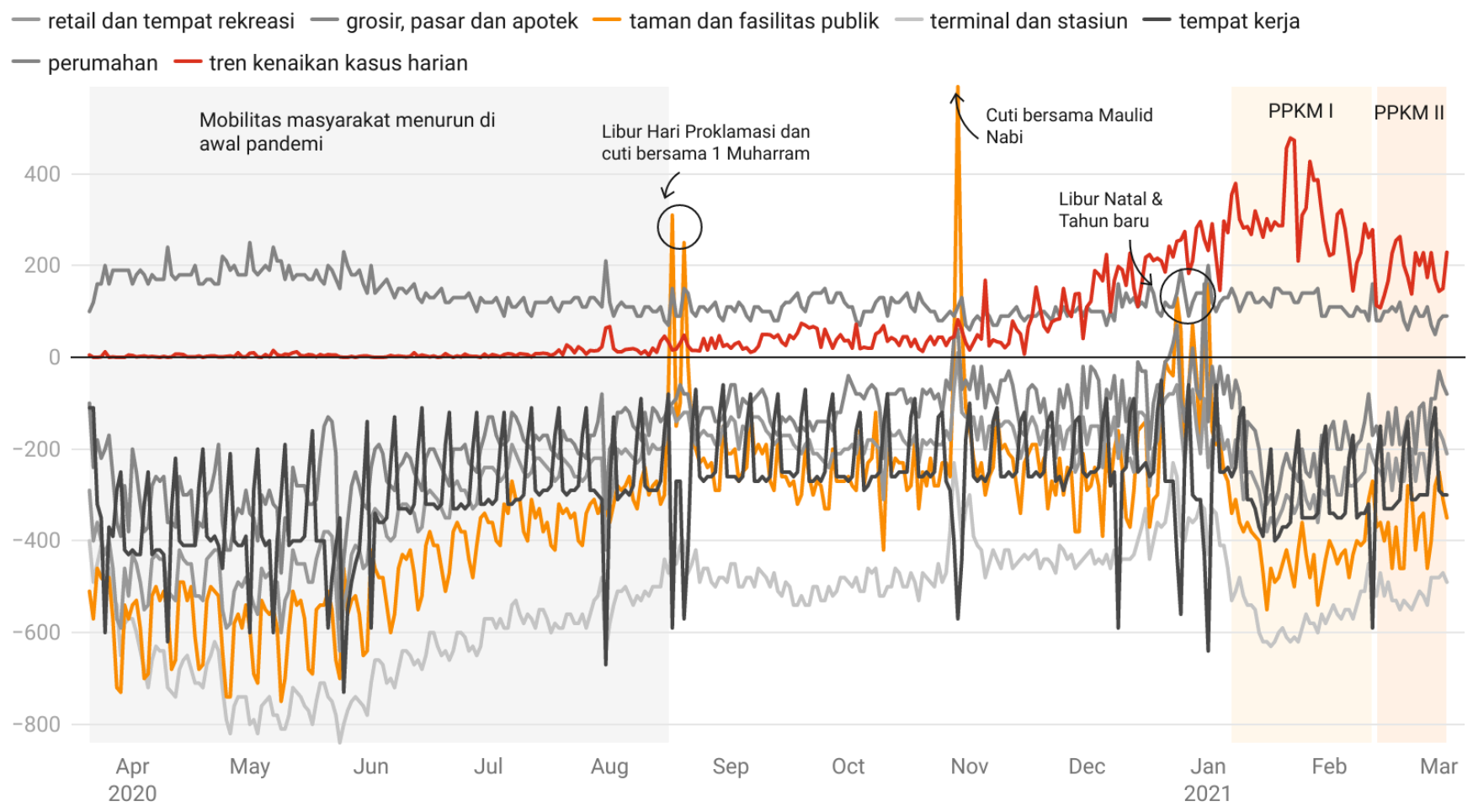

Gbr. 1 Tren mobilitas masyarakat ditinjau dari tempat-tempat terjadinya mobilitas.

PPKM tahap II. Terlihat pula bahwa grafik mobilitas pada kategori 'perumahan' berada di atas baseline. Ini berarti pada masa pandemi memang banyak masyarakat yang tetap tinggal di rumah.

Gbr. 1 juga menunjukkan kondisi-kondisi khas yang terkait dengan kejadian-kejadian (events) tertentu. Tiap kali ada libur yang cukup panjang, terjadi lonjakan mobilitas pada kategori 'taman dan fasilitas publik', yang menunjukkan banyaknya kunjungan masyarakat ke tempat-tempat wisata atau keramaian publik lainnya. Situasi seperti ini umum dijumpai pada daerah tujuan wisata seperti Provinsi DIY.

Secara visual, tampak pula bahwa kenaikan kasus harian muncul dan diamplifikasi oleh mobilitas masyarakat pada saatsaat libur panjang (long weekend). Hal ini ditunjukkan oleh lonjakan-lonjakan (spikes) pada grafik-grafik mobilitas yang kemudian memicu kenaikan kasus harian secara signifikan. Lonjakan mobilitas pada liburan Hari Proklamasi dan cuti bersama 1 Muharram pada bulan Agustus belum secara signifikan menaikkan kasus harian. Namun, ketika terjadi lonjakan mobilitas yang tinggi pada libur dan cuti bersama Maulid Nabi Muhammad pada akhir bulan Oktober, penambahan kasus harian pun menjadi mulai meningkat secara signifikan.

\section{B. Analisis Korelasi}

Hasil perhitungan analisis korelasi antar variabel untuk seluruh data pada rentang waktu 21 Maret 2020 sampai 3 Maret 2021 tersaji pada Tabel I. Tabel I menunjukkan korelasi positif antar sebagian besar variabel mobilitas yang tinggi (kecuali variabel 'tempat kerja'). Hal ini ditunjukkan dengan koefisien korelasi di atas 0,82 . Korelasi positif yang tinggi antar variabel mobilitas menunjukkan fakta bahwa ketika masyarakat merasa aman untuk bepergian, mereka akan pergi melakukan aktivitas di berbagai tempat yang tidak berasosiasi dengan pekerjaan, seperti pergi ke tempat rekreasi, pusat perbelanjaan, tempattempat publik lainnya, atau bepergian ke luar kota melalui terminal dan stasiun. Sebaliknya, bila masyarakat merasa harus mengerem mobilitas, kunjungan ke tempat-tempat tersebut juga menurun. Variabel 'perumahan' menunjukkan korelasi negatif terhadap semua variabel mobilitas, yang menunjukkan fakta logis: semakin sering orang bepergian, semakin jarang orang tersebut tinggal di rumah.

Fakta menarik yang ditunjukkan Tabel I adalah rendahnya korelasi antara kenaikan kasus harian Covid-19 dengan semua variabel mobilitas (ditunjukkan dengan koefisien korelasi bervariasi dari 0,03 sampai 0,33). Hasil ini seolah-olah menunjukkan bahwa penyebaran Covid-19 tidak tergantung pada mobilitas penduduk, berbeda dengan pemahaman masyarakat pada umumnya. Hal ini dapat dijelaskan bahwa pada saat awal pandemi, terjadi perubahan tren mobilitas yang besar (masyarakat mengurangi bepergian dan lebih banyak tinggal di rumah). Dengan demikian, terjadi social distancing yang baik sehingga tingkat penyebaran Covid-19 rendah. Penjelasan ini diperkuat dengan korelasi negatif antara pertambahan kasus harian dengan variabel 'perumahan' (koefisien korelasi -0,22). Data ini menunjukkan bahwa semakin banyak orang tinggal di rumah, semakin rendah kelajuan pertambahan kasus harian Covid-19.

Situasi berubah sekitar bulan Agustus ketika masyarakat mulai merasa bosan tinggal di rumah dan kebetulan ada dua hari libur yang memberi 'saluran' bagi masyarakat untuk menghilangkan kebosanannya. Terjadilah lonjakan mobilitas 
TABEL I

KoEFISIEN Korelasi ANTAR VARIABEL (PERIODE 21-03-2020 SAMPAI 03-03-2021)

\begin{tabular}{|c|c|c|c|c|c|c|c|}
\hline & \begin{tabular}{|c|} 
Retail dan \\
Tempat Rekreasi
\end{tabular} & $\begin{array}{c}\text { Grosir, Pasar, } \\
\text { dan Apotek }\end{array}$ & $\begin{array}{c}\text { Taman dan } \\
\text { Fasilitas Publik }\end{array}$ & \begin{tabular}{|} 
Terminal dan \\
Stasiun
\end{tabular} & $\begin{array}{c}\text { Tempat } \\
\text { Kerja }\end{array}$ & Perumahan & $\begin{array}{c}\text { Kenaikan } \\
\text { Kasus Harian }\end{array}$ \\
\hline $\begin{array}{l}\text { Retail dan } \\
\text { Tempat Rekreasi }\end{array}$ & 1,00 & & & & & & \\
\hline $\begin{array}{l}\text { Grosir, Pasar } \\
\text { dan Apotek }\end{array}$ & 0,93 & 1,00 & & & & & \\
\hline $\begin{array}{l}\text { Taman dan } \\
\text { Fasilitas Publik }\end{array}$ & 0,90 & 0,84 & 1,00 & & & & \\
\hline $\begin{array}{l}\text { Terminal dan } \\
\text { Stasiun }\end{array}$ & 0,87 & 0,86 & 0,82 & 1,00 & & & \\
\hline Tempat Kerja & 0,38 & 0,27 & 0,14 & 0,34 & 1,00 & & \\
\hline Perumahan & $-0,79$ & $-0,68$ & $-0,56$ & $-0,68$ & $-0,70$ & 1,00 & \\
\hline $\begin{array}{l}\text { Kenaikan Kasus } \\
\text { Harian }\end{array}$ & 0,25 & 0,24 & 0,18 & 0,33 & 0,03 & $-0,22$ & 1,00 \\
\hline
\end{tabular}

TABEL II

KoEfisien Korelasi ANTAR VARIABEl (Periode 29-10-2020 SAMPAi 10-01-2021)

\begin{tabular}{|l|c|c|c|c|c|c|c|}
\hline & $\begin{array}{c}\text { Retail dan } \\
\text { Tempat Rekreasi }\end{array}$ & $\begin{array}{c}\text { Grosir, Pasar, } \\
\text { dan Apotek }\end{array}$ & $\begin{array}{c}\text { Taman dan } \\
\text { Fasilitas Publik }\end{array}$ & $\begin{array}{c}\text { Terminal } \\
\text { dan Stasiun }\end{array}$ & $\begin{array}{c}\text { Tempat } \\
\text { Kerja }\end{array}$ & Perumahan & $\begin{array}{c}\text { Kenaikan } \\
\text { Kasus Harian }\end{array}$ \\
\hline $\begin{array}{l}\text { Retail dan } \\
\text { Tempat Rekreasi }\end{array}$ & 1,00 & & & & & & \\
\hline $\begin{array}{l}\text { Grosir, Pasar } \\
\text { dan Apotek }\end{array}$ & 0,86 & 1,00 & & & & & \\
\hline $\begin{array}{l}\text { Taman dan } \\
\text { Fasilitas Publik }\end{array}$ & 0,73 & 0,60 & 1,00 & & & & \\
\hline $\begin{array}{l}\text { Terminal dan } \\
\text { Stasiun }\end{array}$ & 0,63 & 0,59 & 0,64 & 1,00 & & & \\
\hline Tempat Kerja & $-0,24$ & $-0,32$ & $-0,61$ & $-0,16$ & 1,00 & & \\
\hline Perumahan & $-0,29$ & $-0,08$ & 0,23 & 0,03 & $-0,63$ & 1,00 & \\
\hline $\begin{array}{l}\text { Kenaikan Kasus } \\
\text { Harian }\end{array}$ & $-0,21$ & 0,06 & 0,03 & 0,09 & $-0,12$ & 0,64 & 1,00 \\
\hline
\end{tabular}

dan sejak itu tingkat penyebaran Covid-19 mulai bergerak naik. Hal ini dikonfirmasi dengan hasil analisis korelasi yang membandingkan data yang sama pada periode 29 Oktober 2020 sampai 10 Januari 2021. Pada periode ini terdapat beberapa hari libur panjang (cuti bersama Maulid Nabi Muhammad dan rangkaian liburan Natal dan tahun baru), yang menyebabkan terjadinya lonjakan-lonjakan mobilitas masyarakat. Tabel II menunjukkan hasil analisis korelasinya. Pada baris terakhir Tabel II tampak ada keterkaitan yang cukup tinggi antara kenaikan kasus harian Covid-19 dengan variabel 'perumahan' (koefisien korelasi 0,64), sementara tingkat korelasi dengan variabel-variabel mobilitas lainnya justru terlihat sangat rendah. Data ini menunjukkan fakta yang seolah berlawanan dengan yang dipercaya masyarakat pada umumnya: bahwa mobilitas saat liburan berpengaruh besar terhadap kenaikan tingkat penularan Covid-19. Penjelasan yang dapat diberikan adalah bahwa lonjakan-lonjakan mobilitas masyarakat yang hanya terjadi pada periode waktu yang pendek (dalam grafik di Gbr. 1 berupa spikes) tidak secara langsung menyebabkan kenaikan kasus harian. Lonjakan mobilitas menyebabkan terjadinya transmisi lokal antar individu, yang kemudian membentuk klaster-klaster Covid-19 pada lingkungan keluarga. Klaster-klaster yang terbentuk di lingkungan perumahan ini yang lebih berkorelasi dengan penambahan kasus harian.

\section{Akuisisi dan Penyiapan Data}

Gbr. 1, Tabel I, dan Tabel II menunjukkan bahwa dengan metode kuantitatif sederhana, berbagai insight tentang relasi antara mobilitas masyarakat dengan tingkat penyebaran Covid19 dapat diperoleh. Dengan memahami karakteristik korelasi antara mobilitas masyarakat dengan kenaikan kasus harian, berbagai keputusan akan dapat diambil dengan dasar yang lebih objektif.

Data untuk analisis kuantitatif seperti yang digunakan dalam penelitian dapat diperoleh dari beberapa sumber yang berbeda. Data mobilitas dalam lingkup global disediakan oleh platformplatform global seperti Google (Covid-19 Community Mobility Reports [24]), Facebook (Data for Good, https://dataforgood.fb.com/), dan Twitter (melalui mekanisme geotag [25]). Data mobilitas juga dapat diperoleh langsung dari perangkat (gadget) yang menjadi property perorangan [18][20]. Data ini biasanya diperoleh dari penyedia layanan 
telekomunikasi. Sementara itu, sumber resmi data penyebaran Covid-19 adalah pemerintah pusat maupun daerah.

Analisis korelasi antara data mobilitas masyarakat dan data penyebaran Covid-19 dapat dilakukan bila keduanya berada dalam bentuk yang siap diolah. Data mobilitas menunjukkan tren atau jumlah pergerakan, sedangkan data penyebaran Covid-19 menunjukkan pertambahan kasus. Dalam makalah ini, data mobilitas dari Covid-19 Community Mobility Report dan data pertambahan kasus Covid-19 dari Pemerintah Provinsi DIY memiliki periode waktu yang sama (harian). Data Covid19 Community Mobility Report dapat diekstrak pada lingkup provinsi sehingga kedua himpunan data merujuk pada area yang sama pula (Provinsi DIY).

Tidak semua sumber data menyediakan data yang siap olah, terutama untuk data mobilitas. Data lokasi telepon seluler atau geotag dari Twitter berbentuk koordinat lintang dan bujur (latitude dan longitude) sehingga data koordinat ini harus diolah terlebih dahulu (preprocessed) untuk menghasilkan data daerah lokasi dan data pergerakan manusia.

Untuk mengetahui daerah/area lokasi pengguna, data koordinat lintang dan bujur harus diubah menjadi nama tempat yang dapat dibaca oleh manusia (human-readable). Proses ini disebut dengan reverse geocoding [26]. Dalam proses reverse geocoding, data koordinat dibandingkan dengan peta wilayah yang juga menggunakan koordinat sebagai referensinya. Untuk query secara statis, metodenya dapat memanfaatkan peta-peta referensi (misalnya yang disediakan oleh situs Humanitarian Data Exchange di URL https://data.humdata.org/), yang diolah dengan tool Geographical Information System (GIS), yang dapat membaca data peta dan menyaring data koordinat berdasarkan atribut lokasi daerah yang melekat pada peta tersebut. Salah satu tool GIS yang bersifat open source adalah QGIS (https://qgis.org/en/site/).

Untuk query secara dinamis, tersedia API-API yang dapat digunakan untuk mengakses sumber daya yang disediakan platform global seperti Google Maps. Salah satu API yang dapat digunakan adalah Nominatim (https://nominatim.org/), yang digunakan oleh OpenStreetMap (OSM) untuk melakukan reverse geocoding. Pencarian objek OSM berdasarkan lokasinya menggunakan query data pada API Nominatim, yaitu "/reverse" dalam format JSON. Nominatim mengembalikan nama lokasi dalam bahasa lokal atau bahasa default perangkat yang digunakan.

Proses pembangkitan data mobilitas pengguna lebih sulit dilakukan karena mobilitas harus diidentifikasi berdasarkan perubahan koordinat lokasi pengguna. Salah satu caranya adalah dengan membangun matriks Origin-Destination (OD) yang menunjukkan lokasi asal dan lokasi tujuan serta frekuensi perpindahan yang terjadi di antara kedua lokasi tersebut. Matriks OD juga dapat dikonstruksi berdasarkan data lokasi telepon seluler [27].

Jika dibandingkan, ada kelebihan dan kelemahan dari masing-masing jenis sumber data. Sumber data yang berbasis platform global menyajikan data dalam bentuk agregat dan sudah terorganisasi menurut waktu, area, dan aspek-aspek penting lain terkait mobilitas masyarakat, sehingga tidak memerlukan banyak pre-processing. Kelemahannya adalah granularitasnya yang kasar, data tidak menjangkau lingkup wilayah yang lebih sempit (Covid-19 Community Mobility Reports yang digunakan ini berhenti pada tingkat provinsi). Sebaliknya, data yang diperoleh langsung dari perangkat pengguna memiliki granularitas yang lebih tinggi, tetapi lebih sulit untuk dilakukan pre-processing terhadapnya. Dengan demikian, sumber data berbasis platform global lebih cocok digunakan untuk wilayah yang luas dan mitigasi yang bersifat makro, sementara untuk lingkup yang lebih sempit dan spesifik, opsi yang memungkinkan adalah menggunakan sumber yang mengambil data langsung dari perangkat pengguna.

\section{KESIMPULAN}

Dengan menggunakan data yang bersifat publik, makalah ini menjelaskan cara analisis korelasi dapat dilakukan untuk mengamati hubungan antara tingkat penyebaran Covid-19 dengan perilaku mobilitas masyarakat. Analisis kasus di Provinsi DIY menunjukkan bahwa dalam rentang waktu antara Maret 2020 sampai dengan Maret 2021, tingkat korelasi antara keduanya relatif rendah (untuk enam variabel mobilitas, koefisien korelasinya berkisar dari 0,03 sampai 0,33 ). Hal ini menunjukkan fenomena umum yang terjadi sepanjang masa pandemi, yaitu masyarakat cenderung untuk menahan diri dari bepergian. Fenomena social distancing yang terjadi akibat penurunan mobilitas masih dapat menahan kenaikan kasus sehingga relatif masih terkontrol.

Pengamatan pada periode waktu yang mengandung lonjakan-lonjakan mobilitas masyarakat akibat adanya beberapa hari libur menunjukkan fenomena yang berbeda. Kenaikan kasus harian berkorelasi cukup tinggi (koefisien korelasi 0,64$)$ dengan variabel 'perumahan', sementara korelasi dengan variabel-variabel mobilitas lainnya cenderung hampir tidak ada (koefisien korelasi berkisar dari -0,12 sampai 0,09). Fenomena ini menunjukkan bahwa proses penyebaran virus Covid-19 lebih ditentukan karakteristiknya oleh klaster-klaster keluarga dibandingkan dengan mobilitas masyarakat.

Hasil analisis yang diperoleh menunjukkan fakta-fakta objektif yang dapat digunakan sebagai dasar dalam pengambilan keputusan dalam rangka mitigasi risiko pandemi Covid-19.

\section{UCAPAN TERIMA KASIH}

Ucapan terima kasih disampaikan kepada Dr. Sayuri Egaravanda yang telah membantu dalam mendapatkan data pertambahan kasus Covid-19 di Provinsi Daerah Istimewa Yogyakarta.

\section{REFERENSI}

[1] (2020) Gugus Tugas Percepatan Penanganan Covid-19, [Online], https://covid19.go.id/peta-sebaran, tanggal akses: 1-Mar-2021.

[2] (2021) Jasa Marga, [Online], https://www.jasamarga.com/public/ id/aktivitas/detail.aspx?title=Prediksi $\% 20205 \% 20$ Ribu $\% 20$ Kendaraan $\%$ 20Kembali\%20ke\%20Jakarta,\%20Jasa\%20Marga\%20Imbau\%20Pengg una\%20Jalan $\% 20$ Hindari\%20Puncak\%20Arus\%20Balik\%20Hari\%20M inggu, tanggal akses: 1-Mar-2021.

[3] M. Jayaweera, H. Perera, B. Gunawardana, dan J. Manatunge, "Transmission of COVID-19 Virus by Droplets and Aerosols: A Critical Review on the Unresolved Dichotomy," Environ. Res., Vol. 188, hal. 118,2020 
[4] (2020) World Health Organization, [Online], https://www.who.int/newsroom/commentaries/detail/transmission-of-sars-cov-2-implications-forinfection-prevention-precautions, tanggal akses: 4-Mar-2021.

[5] (2020) Kementrian Kesehatan Republik Indonesia, [Online], https://covid19.go.id/storage/app/media/Protokol/2020/Juli/REV05_Pedoman_P2_COVID-19_13_Juli_2020.pdf, tanggal akses: 4-Mar2021.

[6] (2020) DetikNews, [Online], https://news.detik.com/berita/d5168247/tak-ikut-terapkan-psbb-total-seperti-dki-pemkot-bogor-pilihpsbmk, tanggal akses: 4-Mar-2021.

[7] (2021) "Instruksi Menteri Dalam Negeri Nomor 03 Tahun 2021," [Online], https://covid19.go.id/p/regulasi/instruksi-menteri-dalamnegeri-nomor-03-tahun-2021, tanggal akses: 4-Mar-2021.

[8] (2020) Kompas Online, [Online], https://regional.kompas.com/ $\mathrm{read} / 2020 / 12 / 31 / 15250031 /$ polemik-pembukaan-malioboro-di-malamtahun-baru-kasus-covid-19-tinggi-hingga?page=all, tanggal akses: 4Mar-2021.

[9] T. Aven dan F. Bouder, "The COVID-19 Pandemic: How can Risk Science Help?," Journal of Risk Research, Vol. 23, No. 7-8, hal. 849-854, 2020.

[10] M. Enserink dan K. Kupferschmidt. "With COVID-19, Modeling Takes on Life and Death Importance," Science, Vol. 367, No. 6485, hal. 14141415, 2020.

[11] A. Wesolowski, C.O. Buckee, K. Engø-Monsen, dan C.J.E. Metcalf, "Connecting Mobility to Infectious Diseases: The Promise and Limits of Mobile Phone Data,” J. Infectious Diseases, Vol. 214, No. 4, hal. S414 S420, Des. 2016

[12] N.M. Ferguson, D.A. Cummings, S. Cauchemez, C. Fraser, S. Riley, A. Meeyai, S. Iamsirithaworn, dan D.S. Burke, "Strategies for Containing an Emerging Influenza Pandemic in Southeast Asia," Nature, Vol. 437, No. 7056, hal. 209-214, 2005.

[13] A. Wesolowski, N. Eagle, A.J. Tatem, D.L. Smith, A.M. Noor, R.W. Snow, dan C.O. Buckee, "Quantifying the Impact of Human Mobility on Malaria," Science, Vol. 338, No. 6104, hal. 267-270, 2012.

[14] D.A. Cummings, R.A. Irizarry, N.E. Huang, T.P. Endy, A. Nisalak, K Ungchusak, dan D.S. Burke, "Travelling Waves in the Occurrence of Dengue Haemorrhagic Fever in Thailand," Nature, Vol. 427, No. 6972, hal. 344-347, 2004

[15] B.T. Grenfell, O.N. Bjornstad, J. Kappey, "Travelling Waves and Spatial Hierarchies in Measles Epidemics," Nature, Vol. 414, No. 6865, hal. 716-23, 2001

[16] K. Linka, M. Peirlinck, F. Sahli Costabal, dan E. Kuhl, "Outbreak Dynamics of COVID-19 in Europe and the Effect of Travel Restrictions," Comput. Methods Biomech. Biomed. Eng., Vol. 23, No. 11, hal. 710-717, Agu. 2020
[17] M.U.G. Kraemer, C.-H. Yang, B. Gutierrez, C.-H. Wu, B. Klein, D.M Pigott, L. du Plessis, N.R. Faria, R. Li, W.P. Hanage, J.S. Brownstein, M. Layan, A. Vespignani, H. Tian, C. Dye, O. G. Pybus, dan S. V. Scarpino, "The Effect of Human Mobility and Control Measures on the COVID-19 Epidemic in China," Science, Vol. 368, No. 6490, hal. 493-497, Mei 2020.

[18] R.A. Ghiffari, "Dampak Populasi dan Mobilitas Perkotaan Terhadap Penyebaran Pandemi Covid-19 di Jakarta," Jurnal Tunas Geografi, Vol. 9, No. 1, hal. 81-88, 2020.

[19] C. Xiong, S. Hu, M. Yang, W. Luo, dan L. Zhang, "Mobile Device Data Reveal the Dynamics in a Positive Relationship Between Human Mobility and COVID-19 Infections," Proc. of the National Academy of Sciences of the United States of America (PNAS), Vol. 117, No. 44, hal. 27087-27089, Nov. 2020.

[20] P. Bonato, P. Cintia, F. Fabbri, D. Fadda, F. Giannotti, P.L. Lopalco, S Mazzilli, M. Nanni, L. Pappalardo, D. Pedreschi, dan F. Penone, "Mobile Phone Data Analytics Against the Covid-19 Epidemics in Italy: Flow Diversity and Local Job Markets During the National Lockdown," arXiv preprint arXiv:2004.11278, 2020

[21] X. Huang, Z. Li, Y. Jiang, X. Li, dan D. Porter, "Twitter Reveals Human Mobility Dynamics During the COVID-19 Pandemic," PloS One, Vol. 15, No. 11, hal. 1-21, 2020

[22] J-F. Mas, "Spatio-Temporal Dataset of COVID-19 Outbreak in Mexico," Data in brief, Vol. 35, hal. 106843, Apr. 2021.

[23] W. Xi, T. Pei, Q. Liu, C. Song, Y. Liu, X. Chen, J. Ma, dan Z. Zhang, "Quantifying the Time-Lag Effects of Human Mobility on the COVID19 Transmission: A Multi-City Study in China," IEEE Access, Vol. 8, hal. 216752-216761, 2020

[24] A. Aktay, S. Bavadekar, G. Cossoul, J. Davis, D. Desfontaines, A Fabrikant, E. Gabrilovich, K. Gadepalli, B. Gipson, M. Guevara, and C. Kamath, "Google COVID-19 Community Mobility Reports: Anonymization Process Description (Version 1.0)," arXiv preprint arXiv:2004.04145, 2020.

[25] W. Rowe (2019) "How to Track Tweets by Geographic Location," [Online], https://www.bmc.com/blogs/track-tweets-location/, tanggal akses 31 Maret 2021.

[26] J.S. Brownstein, C. Cassa, I.S. Kohane, dan K.D. Mandl, "Reverse Geocoding: Concerns About Patient Confidentiality in the Display of Geospatial Health Data," Proceedings of the American Medical Informatics Association (AMIA) Annual Symposium, 2005, hal. 905.

[27] L. Alexander, S. Jiang, M. Murga, and M.C. González, "OriginDestination Trips by Purpose and Time of Day Inferred from Mobile Phone Data," Transportation Research Part C: Emerging Technologies, Vol. 58, Part B, hal.240-250, 2015. 